\title{
Relevance of wing morphology in distinguishing and classifying genera and species of Stenogastrinae wasps
}

\author{
David Baracchi ${ }^{1,2}$, Leonardo Dapporto $^{1}$, Stefano Turillazzi $^{1}$ \\ ${ }^{1}$ Università degli Studi di Firenze, Dipartimento di Biologia Evoluzionistica 'Leo Pardi', Via Romana 17, 50125, \\ Firenze, Italy \\ ${ }^{2}$ E-mail: david.baracchi@gmail.com
}

Key words: geometric morphometrics, Hymenoptera, nest architecture, taxonomy, Vespidae

\begin{abstract}
The phylogeny of the Stenogastrinae wasps is still under discussion and their systematic incomplete. In the present work we used geometric morphometrics, a technique based on a rigorous statistical assessment of shape, to compare the forewings of fifteen species of Stenogastrinae wasps belonging to four different genera to ascertain whether this approach may be used as a reliable method in the study of the taxonomy of the group. The results show that the wing vein junctions can be diagnostic for both genus and species identification. For the first time in this subfamily, we propose a phylogenetic classification of the species based on wing morphology that largely agrees with the cladistic data available at genus level and reflects the differences among species in terms of nesting material and architecture of their nest.
\end{abstract}

\section{Contents}

Introduction 191

Material and methods

Samples collection ……………………………………...... 192

Geometric morphometrics analyses ................................. 193

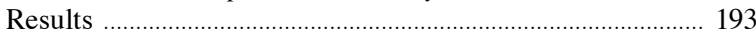

Geometric morphometrics analyses ................................ 193

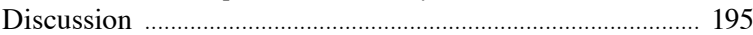

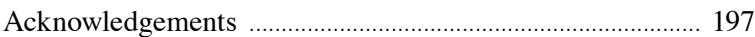

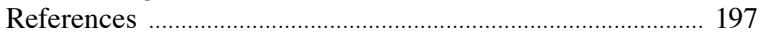

\section{Introduction}

The Stenogastrinae represent a sub-family of social wasps belonging to the family Vespidae (Carpenter, 1982; Hines et al., 2007). Stenogastrinae are endemic to the Indo-Malaysian area and comprise 57 described species belonging to seven genera among which Eustenogaster, Liostenogaster and Parischnogaster show the highest number of taxa described so far (Carpenter, 2001). Due to the primitive social organization and to the generalized small size of the colonies, exceeding a dozen individuals in a very few species (Baracchi $e t$ al., 2009a), these organisms have been proposed as a key group for understanding the origin of social evolution in insects (Yoshikawa et al., 1969; West-Eberhard, 1978; Turillazzi, 1991). Several of their features, like the elaborate larval rearing (Turillazzi, 1989), the long larval developmental time (Field et al., 2000) and the poor quality of nest material (Hansell, 1987) are considered as important determinants in shaping their peculiar social structure. The most generally accepted phylogenetic hypothesis (Carpenter, 1982, 1988; Carpenter and Starr, 2000) collocates them as the sistergroup of the Polistinae + Vespinae, rendering the social wasps as an entirely monophyletic group. However, a recent study by Hines et al. (2007), comparing mitochondrial and nuclear DNA, indicated a clade composed of these three subfamilies as non-monophyletic and implied a separate route to eusociality for the Stenogastrinae. The noticeable discrepancy between these two contrasting hypotheses underlines the need for further studies in order to clarify the taxonomy of the Stenogastrinae wasps and to better understand their systematic at the subfamily, genera and species levels. Data concerning the phylogenetic relationships among species within the group are still missing except for the ones recently obtained for a few species belonging to the Liostenogaster, Eustenogaster and Parischnogaster genera through chemical taxonomy (Baracchi et al., 2009b). Taxonomists usually identify species using operational methods, based on phenotypic morphological evidence, on molecular (phylogenetics) and on chemical characters (Agapow et al., 2004; Haverty et al., 2005; Dapporto, 2007; Hines et al., 2007; Baracchi et al., 2009b). Furthermore, in the Stenogastrinae, characteristics of the nest architecture have also been used to discriminate between morphologically 


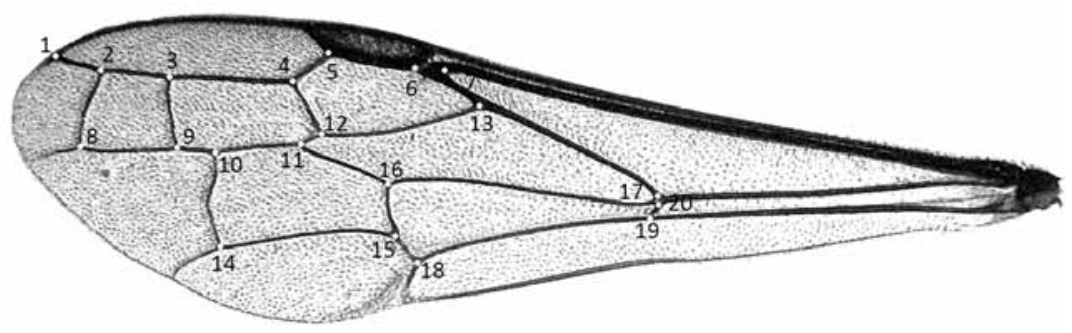

Fig. 1. Calculated landmark points positioned at vein junctions, used in forewing geometric morphometrics analyses of Stenogastrinae species. similar species (Sakagami and Yoshikawa, 1968). Classical morphometric methods (Ruttner, 1988), based on multiple measurement of many individuals (Alpatov, 1929) evolved in geometric morphometrics (Bookstein, 1991). This technique is based on a rigorous statistical theory of shape (Kendall et al., 1999) that allows quantitative multivariate analyses on structure shapes (Rohlf and Marcus, 1993; Adams et al., 2004). While some authors suggest that the use of geometric morphometrics data for reconstruction of phylogenies could be problematic (MacLeod and Forey, 2002), there is also mounting evidence supporting the use of this technique in insect systematics studies. Actually, the geometric morphometrics applied to vein junctions of the wings has already been successfully used to discriminate honeybee subspecies (Tofilski, 2008), Sphex species (Tuzun, 2009), and some species of Syrphidae (Francuski et al., 2009).

In the present work geometric morphometrics was applied to forewings of 15 species belonging to four genera of Stenogastrinae wasps to assess whether this approach may contribute to taxonomic studies and whether wing morphology of Stenogastrinae shows any correlation with their phylogeny at the genus level. Finally, we provide, for the first time in the subfamily, a dendrogram showing a phylogenetic classification of the species based on wing morphology.

\section{Material and methods}

\section{Samples collection}

Forewings of the following Malaysian Stenogastrinae species were collected in the field and used in this study: Eustenogaster calyptodoma (Sakagami and Yoshikawa, 1968), E. micans (de Saussure, 1852), E. fraterna (Bingham, 1897), Liostenogaster campanulae (Turillazzi, 1999), L.flavolineata (Cameron, 1902), L. nitidipennis (de Saussure, 1952), L. pardii (Turillazzi and Carfì, 1996), L. topographica (Turillazzi, 1999), L. vechti (Turillazzi, 1988), Metischnogaster drewseni (de Saussure, 1857), Parischnogaster alternata (Sakagami, 1969), P. mellyi (de Saussure, 1852), P. jacob-

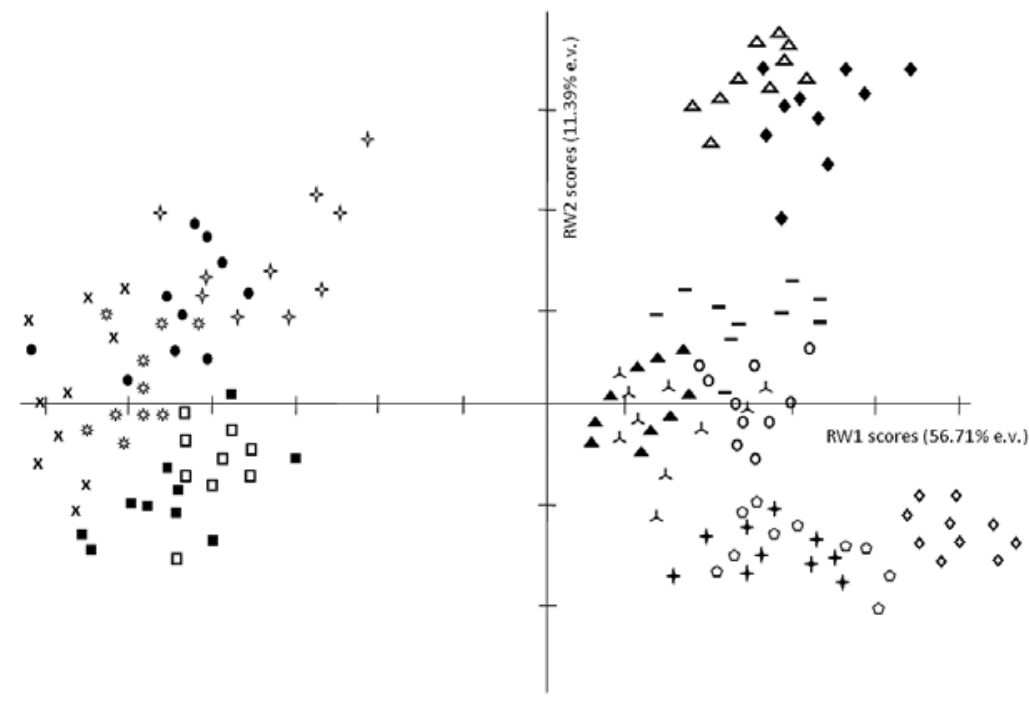

Fig. 2. Graphical representation of the first (x-axis) and of the second (y-axis) Relative Warp (RW) of the forewing vein junctions analysis. Open pentagons, E. calyptodoma; black stars, E. micans; open rhombus, E. fraterna; triad, L. campanulae; black triangles, $L$. flavolineata; open triangles, L. nitidipennis; open circles, L. pardii; black rhombus, L. topographica; black rectangles, L. vechti; open squares, $M$. drewseni; black circles, $P$. alternata; black squares, P. mellyi; X-shaped, P. jacobsoni; sun-shaped, Parischnogaster sp., open stars, $P$. striatula. 
soni (du Buysson, 1913), Parischnogaster sp., P. striatula (du Buysson, 1905). Parischnogaster sp. is an undescribed species but it is quite common in Malaya peninsula (pers. obs. DB) and it belongs to the Parischnogaster genus characterized by a very narrow petiole of the gaster and distinctly longer than wide, clypeus widely separated from the eye and posterior ocelli separated by more than one ocellus diameter. Its nest is similar to that of $P$. jacobsoni but it is often spread on a flat surface like a leaf (with each cell separate from the others) and equipped with an Ant-guard. All the samples (ten females for each species, except for $M$. drewseni for which only 9 females were used; each specimen from a different colony) were collected in $\mathrm{Pa}-$ hang State in peninsular Malaysia during FebruaryMarch 2008 and killed by freezing soon after capture. As nest architecture is important for species identification, we collected the specimens directly on the comb. Since male wasps disperse soon after emergence, we focused on females. Some specimens were collected at various sites in Bukit Fraser (N 343.658 E 10142.654), others at various localities around Kuala Lumpur: Ulu Langat (N $3^{\circ} 05.432$ E 10149.843), Ulu Gombak (N $3^{\circ} 32.483$ E $\left.101^{\circ} 75.3156\right)$, Genting Sempah (N $3^{\circ} 21.363$ E 101 $\left.{ }^{\circ} 47.683\right)$, Janda Baik (N $3^{\circ} 31.541$ E 101 $\left.{ }^{\circ} 53.261\right)$ and Genting Highland (N $3^{\circ} 25.803$ E 1014․839).

\section{Geometric morphometrics analyses}

The left forewing of each wasp (total 149 wings) was removed from the body and mounted in Euparal between a microscope slide and a cover slip. Wings were photographed using a Canon Power Shot A570 camera mounted on a binocular microscope. The vein junctions were used as landmarks for geometric morphometrics (Fig. 1).

The tps (Thin-plate-spline) series of programs were used in these analyses (Rohlf, 2006, 2007). The landmark digitations on wings photographs were carried out using tspdig 2.10 (Rohlf, 2006). The complete dataset (wings photographs, tpsdig landmark files are available as Supplementary Online Information). Generalized Procrustes Analysis (GPA) was first applied to the landmark data to remove non-shape variations in location, scale, and orientation and to superimpose the objects in a common coordinate system (Rohlf and Slice, 1990). GPA removes variations in scale, but information about size is retained in a single variable (centroid size). Landmarks configuration after GPA can be used in stepwise discriminant analysis (DA) to test whether specimens can be correctly attributed to their species group. We provided the average landmarks configuration because it can be used as a reference for future studies (Francoy et al., 2008). Moreover, using the shape residual from GPA, the Partial Warps, that are sets of variables containing shape information, were calculated. Applying the PCA principle to Partial Warps, we obtained Relative Warps (RW) that could be used as variables in stepwise discriminant analysis (DA). RW can be visualized by thin-plate-spline deformation grids, which allow a visual comparison of shape differences. GPA, Partial and Relative Warps calculations and thin-plate-spline visualization were carried out using TPSRELW 1.45 (Rohlf, 2007). Since the number of RW was high, only RW explaining more than $1 \%$ of variance were used in DA. The significance of Wilks' lambda and the percentage of correct assignments were used to estimate the validity of the discriminant functions. Moreover, we performed a complete cross-validation test using the leave-one-out technique in order to obtain a conservative test for the discriminant analyses. The percentage of cases blindly assigned to their actual species was used as a definitive indication of the reliability of the analysis in assigning specimens to their correct group on the basis of wing geometric morphometrics.

To evaluate the role of the wing size in discrimination among different species we compared the centroid size values by ANOVA comparison using Tukey's-b post hoc test to identify possible homogeneous subsets of species showing comparable wing size.

Finally, we specifically focused on the pattern among species by creating a new matrix composed by mean RW values for each species. A Cluster Analysis, using the average linkage (UPGMA) method and squared Euclidean distance among mean RW value as a dissimilarity measure, was used to group the samples in a hierarchical tree. All statistical analyses were performed using the statistical program SPSS $®$ 13.0.

\section{Results}

\section{Geometric morphometrics analyses}

Among the 40 Cartesian coordinates belonging to the 20 superimposed landmarks, 21 entered the DA model (Function 1: Wilks' $\lambda<0.001, \mathrm{P}<0.001$, explained variance $35.3 \%$; Function 2: Wilks' $\lambda<0.001, \mathrm{P}<0.001$, explained variance $23.6 \%$ ). Moreover the $93.3 \%$ of the cases were correctly assigned to their group in the 


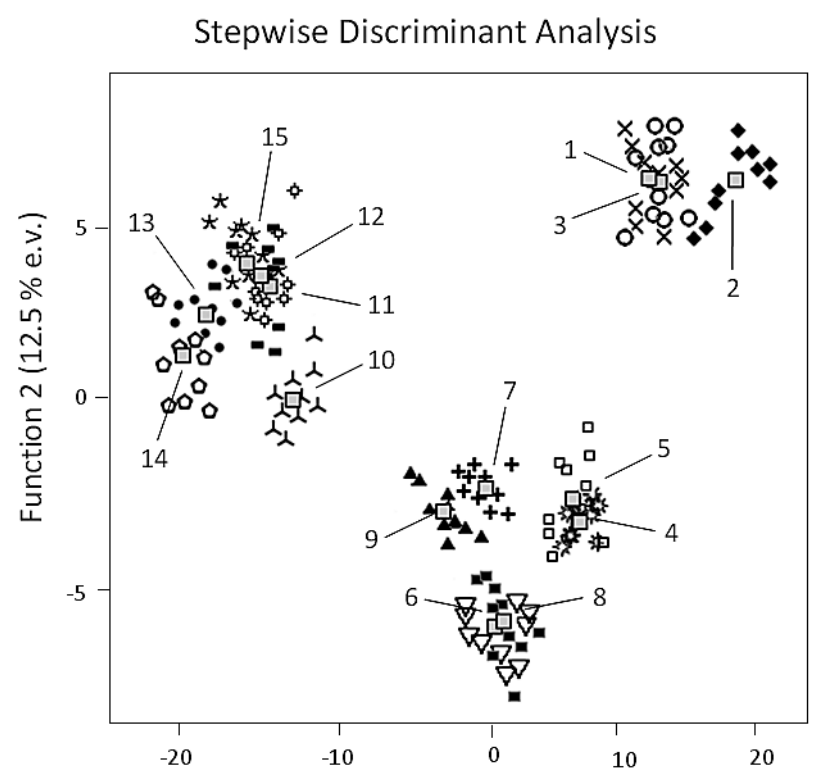

Species

$\times 1$ E. calyptodoma

O E. fraterna

- 3 E. micans

is 4 L. campanulae

口 5 L. flavolineata

$\nabla 6$ L. nitidipennis

+ 7 L. pardii

- 8 L. topographica

- 9 L. vechti

ᄉ 10 M. drewseni

古 11 P. alternata

- 12 P. mellyi

13 P. jacobsoni

$\bigcirc 14$ P. sp

* 15 P. striatula

$\square$ Centroid

Fig. 3. Plot of the scores of the two first discriminant functions obtained from the stepwise discriminant analysis of 15 Stenogastrinae species, with $69.1 \%$ and $12.5 \%$ of variance explained, respectively.

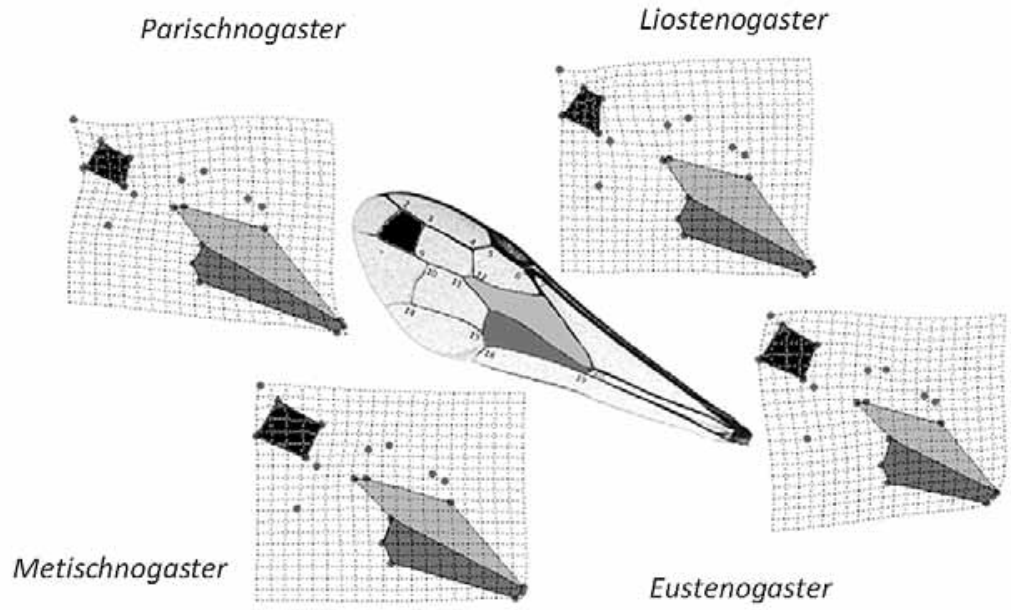

Fig. 4. Variation in shape of the four genera of Stenogastrinae wings are shown in thin-plate-spline deformation grides. The major wing cells deformation are the one-brachial cell (dark grey region), the one-discoidal cell (grey region) and the three-cubital cell (black region). cross-validation test. Average landmark configurations for each species are reported in Electronic appendix.

We obtained 36 Relative Warps through wings analysis. Ten RW explained more than $1 \%$ of the variance (explaining a cumulative variance of 93.63\%) and were then included in successive analyses (Fig. 2).

Stepwise discriminant analysis correctly assigned $98.7 \%$ of the females to their species (Function 1: Wilks' $\lambda<0.001, \mathrm{P}<0.001$, explained variance $69.1 \%$; Function 2: Wilks' $\lambda<0.001, \mathrm{P}<0.001$, explained variance $12.5 \%$, Fig. 3).
In particular, all specimens were correctly assigned with the exception of two E. calyptodoma erroneously assigned to E. micans and two L. campanulae to L. flavolineata. Intriguingly, Function 1 represented by the variables RW1 and RW4 while Function 2 by the variables RW2 and RW3. In the cross-validation test, where specimens were blindly entered into the analysis only 7 out of 149 cases were misclassified in different congeneric species $(94.6 \%$ of correct classification): three L. campanulae were identified as L. flavolineata, two E. calyptodoma as E. micans, one $P$. striatula as $P$. alternata and one P. jacobsoni 
Table 1. Relative contribution of each landmark point (vein junctions) measured as the 'Sum of Squares' recorded from the GPA configuration.

\begin{tabular}{llll}
\hline Landmark & Sum of Squares & Landmark & Sum of Squares \\
\hline 1 & 0.001 & 11 & 0.030 \\
2 & 0.002 & 12 & 0.031 \\
3 & 0.001 & 13 & 0.003 \\
4 & 0.004 & 14 & 0.001 \\
5 & 0.003 & 15 & 0.004 \\
6 & 0.009 & 16 & 0.003 \\
7 & 0.013 & 17 & 0.287 \\
8 & 0.001 & 18 & 0.002 \\
9 & 0.013 & 19 & 0.048 \\
10 & 0.014 & 20 & 0.529 \\
\hline
\end{tabular}

as $P$. mellyi. Differences between genera in wing shape are illustrated by deformation grids reported in Figure 4. As shown in Table 1, the landmarks 17 and 20 gave the major contribution to the variation in shape of the forewing (see also Fig. 1).

ANOVA test and Tukey's-b post hoc test identified nine homogeneous subsets of species with comparable wing size (Fig. 5). Out of 15 species only Parischnogaster sp., L. nitidipennis, L. campanulae and E. fraterna had a specific wing size different from any other species.

Cluster Analysis, provided a dendrogram based on wing shape (Fig. 6) largely congruent with the tree obtained by cladistic studies (Carpenter, 1988), with the genera Eustenogaster and Liostenogaster branched from Parischnogaster and Metischnogaster. However the Cluster Analysis grouped the Eustenogaster species with the Liostenogaster ones, while in the cladogram (Carpenter, 1988), Liostenogaster is sister to all other genera. As consequence of this layout Liostenogaster species are split in two groups and some of them (L. campanulae, L. flavolineata, L. pardii and $L$. vechti) appeared nearer to the Eustenogaster ones than to the congeneric L. topoghaphica and L. nitidipennis (Fig. 6). Moreover, the Parischnogaster species are readily sub-grouped in P. alternata and $P$. striatula (both belonging to the striatula-group) and $P$. jacobsoni, P. mellyi and Parischnogaster sp. (all belonging to nigricans-group) (Fig. 6).

\section{Discussion}

The present study shows that the wing morphology of primitively eusocial hover wasps can be diagnostic for genus and species identification. The high number of the vein junctions in the Stenogatrinae, implied the use of a relatively large number of landmarks and a consequent large number of shape variables (i.e. Partial Warps). The potential redundancy of some of them can be handled recurring to Relative Warps analysis that applies to Partial Warps the PCA algorithm and by using the Stepwise Method in discriminant analysis entering into the model only the most predictive variables. Moreover, a high number of predictor variables may result in identifying casual associations between the grouping variables and one of the many predictors. In this case, however, cross-validation test is predicted to fail in making correct blind attributions. In our study, the stepwise DA was effective in assigning most of the specimens to their correct group also in the cross-validation tests. The fact that Relative Warps explaining most variance (i.e. RW1 and RW2 explaining together $68.1 \%$ of the variance) entered the first two discriminant functions give evidence that most shape variation is involved in species discrimination.

By examining the thin-plate-spline deformation grids, the wing regions contributing to the discrimination can be easily recognized (Fig. 4). The major wing cells deformation are in the 1-brachial cell (defined by vein junctions 16-19), in the 1-discoidal cell (defined by vein junctions 11-13, 16-17) and in the 3-cubital cell (defined by vein junctions 2-3-8-9), (Fig. 4). The deformation of these cells are mainly due to the major relative displacements of the landmarks (vein junctions) 20-19-17, 11-12 and 9-10 (see also Table 1).

Also in the Cluster Analysis, where an overall distance matrix among the species is analyzed without any a priori indication of group membership, genera identification seems correct matching both cladistic (Carpenter, 1988) and chemical taxonomy studies (Baracchi et al., 2009b). In particular, as for chemical polar epicuticular compounds (Baracchi et al., 2009b) Parischnogaster species were well separated by the Cluster Analysis in two sub-groups (P.alternata and $P$. striatula vs $P$. jacobsoni, $P$. mellyi and Parischnogaster sp.), according to the two species-groups of this genus occurring in the peninsular Malaysia. More precisely, P. alternata and P. striatula are members of the striatula-group, characterized by a petiole of the gaster only about as long as wide, clypeus narrowly separated from eye and posterior ocelli separated at most one ocellus diameter. $P$. jacobsoni and P. mellyi are members of the nigricans-group (as well 


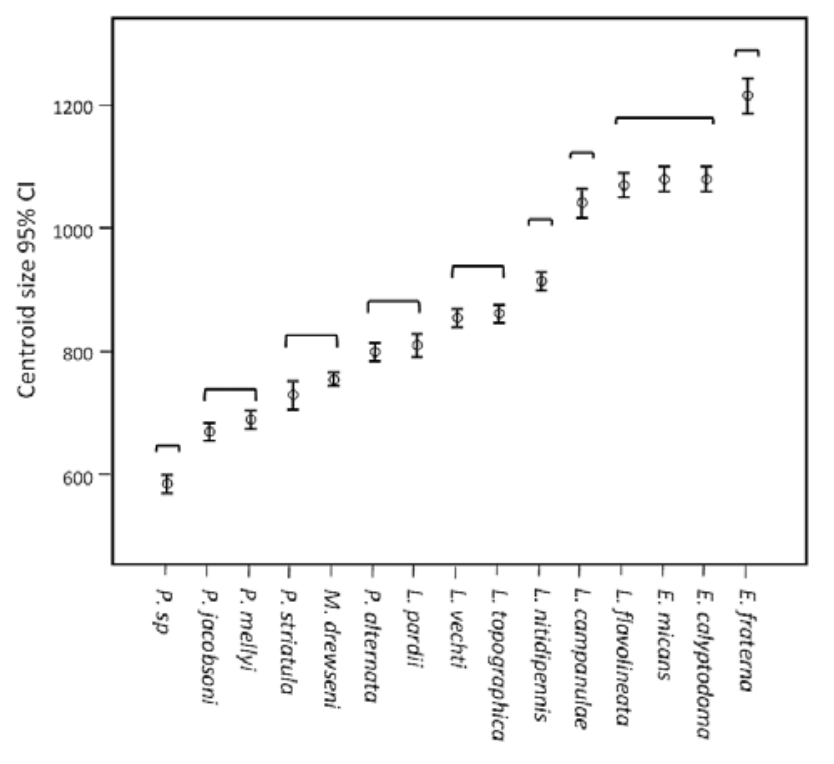

Fig. 5. Plot of mean centroid size $\pm 95 \%$ confidential interval for the 15 species analysed. Parenthesis groups species identified as homogeneous subset by Tukey's-b post hoc test.

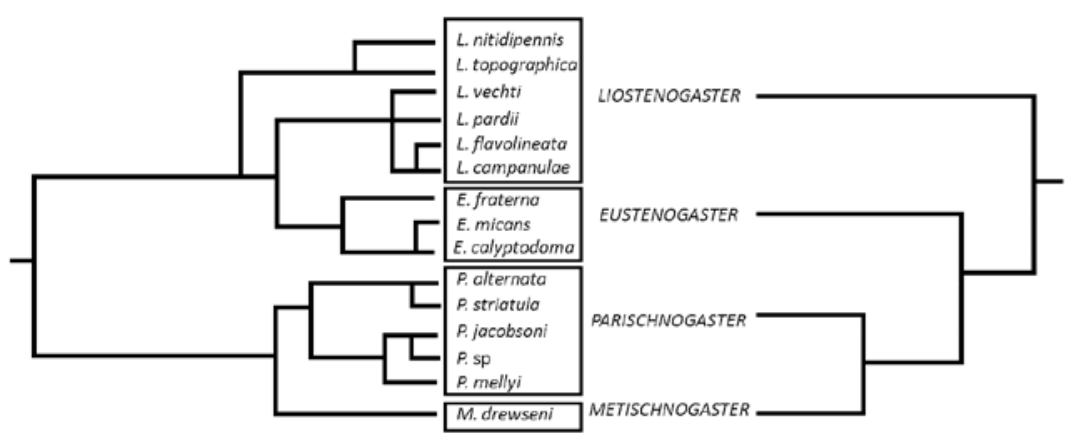

Fig. 6. Dendrogram Scaling displaying relative positions of the 15 species in the overall Euclidean distances similarities among RW. On the right a simplified cladogram for genera of Stenogastrinae after Carpenter (1988). as Parischnogaster sp.) characterized by a petiole of the gaster very narrow and distinctly longer than wide, clypeus widely separated from the eye and posterior ocelli separated by more than one ocellus diameter. Still, interestingly, in the dendrogram (Fig. 6), L. campanulae, L. flavolineata, and L. pardii are separated from L. nitidipennis and L. topographica (although data regarding chemical taxonomy are lacking for $L$. nitidipennis, the distance between $L$. topographica and the other Liostenogaster species was found also in the chemical polar cuticular compounds, (Baracchi et al., 2009b)). These groups agreed with the classification of their nests which are distinguishable on the basis of nesting material (paper vs mud) and architecture (flat, spread on the substrate and delicate vs hanging and heavy) suggesting a possible evolutionary route linked to nest architecture in this subfamily. These findings appear more interesting when considering that the Stenogastrinae nests are deeply variable in architecture and their appearance has often been used to discriminate among very similar species (Sakagami and Yoshikawa, 1968). However, from this point of view, the position of $L$. vechti (a species with flat paper nests) seems a bit problematic because it is grouped near to the species with 'mud and heavy nest', by the Cluster Analysis (Fig. 6). This ambiguous classification may be explained by the intermediate position of $L$. vechti between the two groups, as shown by the graphical representation of the first and of the second RW, (Fig. 2). Additional evidence according to these findings comes from the chemical polar profile of the epicuticular layer of $L$. vecht $i$ which shows an intermediate composition between this of L. topographica which builds a paper nests and those of other Liostenogaster species which build mud nests (Baracchi et al., 2009b).

In conclusion, our results demonstrate that the ge- 
ometric morphometrics measurements are consistent with species-specific patterns and with phylogeny at the genus level in Stenogastrinae. Moreover, these results are, at present, the only available data at the species level for this subfamily except for those provided by Carpenter (1988) and Baracchi et al. (2009b). Therefore the geometric morphometrics studies represent a reliable tool in taxonomy and phylogeny research.

\section{Acknowledgements}

We thank Mr Henry Barlow, Mr Simon Hok and the staff of the Institute of Biological Sciences of the University of Malaya for their support in Malaysia (director Prof. Rosli Bin Hashim). Thanks to Dr. Serafino Teseo for helping in collecting samples in Malaysia and Dr. Federico Cappa for helpful comments on the manuscript. We thank also anonymous referees for comments and suggestions for improvement of our manuscript.

\section{References}

Adams DC, Slice DE, Rohlf FJ. 2004. Geometric morphometrics: ten years of progress following the 'revolution'. Italian Journal of Zoology 71: 5-16.

Agapow PM, Bininda-Edmonds ORP, Crandall KA, Gittleman JL, Mace GE, Marshall JC, Purvis A. 2004. The impact of species concept on biodiversity studies. Quarterly Review of Biology 79: 161-179.

Alpatov WW. 1929. Biometrical studies on variation and races of the honey bee (Apis mellifera L.). Quarterly Review of Biology 4: 1-58.

Baracchi D, Hashim R, Teseo S, Turillazzi S. 2009a. Basic social biology and nest architecture of Liostenogaster topographica Turillazzi 1999. (Hymenoptera Stenogastrinae). Tropical Zoology 22: 15-25.

Baracchi D, Dapporto L, Teseo S, Hashim R, Turillazzi S. 2009b. Medium molecular weight polar substances of the cuticle as tools in the study of the taxonomy, systematics and chemical ecology of tropical hover wasps (Hymenoptera: Stenogastrinae). Journal of Zoological Systematics and Evolutionary Research 48: 109-144.

Bingham CT. 1897. Fauna of British India, including Ceylon and Burma. Wasps and Bees, Vol. 1. Hymenoptera. Taylor \& Francis, London.

Bookstein FL. 1991. Morphometric tools for landmark data: Geometry and Biology. Cambridge: Cambridge University Press.

Buysson R du. 1913. Ischnogaster jacobsoni. Bulletin de la Musee d'Histoire Naturelle de Paris 7: 436.

Buysson R du. 1905. Ischnogaster striatulus. Bulletin de la Société entomologique de France: 282.

Cameron S. 1902. Ischnogaster flavolineata. Journal of the Straits Branch Royal Asiatic Society 37: 108.
Carpenter JM. 1982. The phylogenetic relationships and natural classification of the Vespoidea (Hymenoptera). Systematic Entomology 7: 11-38.

Carpenter JM. 1988. The phylogenetic system of the Stenogastrine (Hymenoptera: Vespidae). Journal of the New York Entomological Society 96: 140-175.

Carpenter JM. 2001. New generic synonymy in Stenogastrinae (Insecta: Hymenoptera; Vespidae). Natural History Bulletin of Ibaraki University 5: 27-30.

Carpenter JM, Starr CK. 2000. A new genus of hover wasps from South East Asia (Hymenoptera: Vespidae; Stenogastrinae). American Museum Novitates 3291: 1-12.

Dapporto L. 2007. Cuticular lipid diversification in Lasiommata megera and L. paramegera: the influence of species, sex, and population (Lepidoptera, Nymphalidae). Biological Journal of Linnean Society 91: 703-710.

Field JP, Shreeves G, Sumner S, Casiraghi M. 2000. Insurancebased advantage to helpers in a tropical hover wasp. Nature 404: 869-871.

Francoy TM, Wittmann D, Drauschke M, Müller S, Steinhage V, Bezerra-Laure MAF, De Jong D, Segui Gonçalves L. 2008. Identification of Africanized honey bees through wing morphometrics: two fast and efficient procedures. Apidologie 39: 488-494.

Francuski L, Ludoški J, Vuji A, Milankov V. 2009. Wing Geometric Morphometric Inferences on Species Delimitation and Intraspecific Divergent Units in the Merodon ruficornis Group (Diptera, Syrphidae) from the Balkan Peninsula. Zoological Science 26: 301-308.

Hansell MH. 1987. Nest building as a facilitating and limiting factor in the evolution of eusociality in the Hymenoptera. Pp. 155-181 in: Harvey P, Partridge L, eds, Oxford Surveys in Evolutionary Biology. Oxford: Oxford University Press.

Haverty MI, Woodrow RJ, Nelson LJ, Grace JK. 2005. Identification of termite species by the hydrocarbons in their feces. Journal of Chemical Ecology 31: 2119-2151.

Hines HM, Hunt JH, O'Connor TK, Gillespie JJ, Cameron SA. 2007. Multigene phylogeny reveals eusociality evolved twice in vespid wasps. Proceeding of the National Academy of Sciences 104: 3295-3299.

Kendall DG, Barden D, Carne TK, Le H. 1999. Shape and shape theory. Chichester: John Wiley \& Sons.

MacLeod N, Forey PL. 2002. Morphology, Shape and Phylogeny. Systematics Association Special Volume. London, New York: Taylor \& Francis for the Systematics Association.

Rohlf FJ. 2006. TPSDIG, version 2.10. Department of Ecology and Evolution, State University of New York at Stony Brook. [available via http://life.bio.sunysb.edu/morph/]

Rohlf FJ. 2007. TPSRELW, version 1.45. Department of Ecology and Evolution, State University of New York at Stony Brook. [available via http://life.bio.sunysb.edu/morph/]

Rohlf FJ, Marcus LF. 1993. A revolution in morphometrics. Trends in Ecology \& Evolution 8: 129-132.

Rohlf FJ, Slice DE. 1990. Extensions of the Procrustes method for the optimal superimposition of landmarks. Systematic Zoology 39: 40-59.

Ruttner F. 1988. Biogeography and taxonomy of honeybees. Berlin: Springer.

Sakagami SF. 1969. Parischnogaster alternata in Yoshikawa $\mathrm{K}$, Ohgushi R, Sakagami SF, eds. Nature and Life in Southeast Asia 6: 155. 
Sakagami SF, Yoshikawa K. 1968. A new ethospecies of Stenogaster wasps from Sarawak, with a comment on the value of ethological characters in animal taxonomy. Annotationes Zoologicae Japonenses 41: 77-84.

Saussure H de. 1852. Description du genre Ischnogaster (Jumnoptres de la famille des Vespides.). Annales de la Societe Entomologique de France 10: 19-27.

Saussure $\mathrm{H}$ de. 1857. Ischnogaster drewseni. Annales de la Société Entomologique de France 5: 315.

Tofilski A. 2008. Using geometric morphometrics and standard morphometry to discriminate three honeybee subspecies. Apidologie 39: 558-563.

Turillazzi S. 1988. Adults and nest of Liostenogaster vechti $\mathrm{n}$. sp. (Hymenoptera Stenogastrinae). Tropical Zoology 1: 193201.

Turillazzi S. 1989. The origin and evolution of social life in the Stenogastrinae (Hymenoptera Vespidae). Journal of Insect Behaviour 2: 649-661.

Turillazzi S. 1991. The Stenogastrinae. Pp. 74-98 in: Ross KG, Matthews RW, eds, The Social Biology of Wasps. New York: Cornell University Press.

Turillazzi S, Carfì S. 1996. Adults and nest of Liostenogaster pardii $\mathrm{n}$. sp. (Hymenoptera Stenogastrinae). Tropical Zoology 9: 19-30.

Turillazzi S. 1999. New species of Liostenogaster van der Vecht 1969, with keys to adults and nests (Hymenoptera Vespidae Stenogastrinae). Tropical Zoology 12: 335-358.

Tuzun A. 2009. Significance of wing morphometry in distinguishing some of the hymenoptera species. African Journal of Biotechnology 8: 3353-3363.

West-Eberhard MJ. 1978. Polygyny and the evolution of social behavior in wasps. Journal of Kansas Entomological Society 51: 832-856.

Yoshikawa K, Ohgushi R, Sakagami SF. 1969. Preliminary report on entomology of the Osaka City University, 5th Scientific Expedition to Southeast Asia 1966. With descriptions of two new genera of stenogasterine [sic] wasps by J. Van der Vecht. Nature Life Southeast Asia 6: 153-182.

Received: 24 March 2010

Revised and accepted: 3 March 2011

Published online: 8 August 2011

Editor: J.A. Miller 


\section{Online supplementary information (SI)}

SI 1: Wing photos of E. calyptodoma

SI 2: Wing photos of E. fraterna

SI 3: Wing photos of E. micans

SI 4: Wing photos of L. campanulae

SI 5: Wing photos of L. flavolineata

SI 6: Wing photos of L. nitidipennis

SI 7: Wing photos of $L$. pardii

SI 8: Wing photos of L. topographica

SI 9: Wing photos of $L$. vechti

SI 10: Wing photos of M. drewseni

SI 11: Wing photos of P. alternata

SI 12: Wing photos of $P$. jacobsoni

SI 13: Wing photos of P. mellyi

SI 14: Wing photos of P. striatula

SI 15: Wing photos of Parischnogaster sp.

SI 16: X-Y coordinates of the 20 landmarks belonging to the forewings of the 15 Stenogastrinae species. 
